Thorax (1972), 27, 207.

\title{
Mitral valve pericardioplasty-a long-term follow-up study
}

\author{
J. C. VAN DER SPUY \\ Division of Cardiothoracic Surgery, University of Pretoria, South Africa
}

\begin{abstract}
Posterior (17) and anterior (3) mitral cusp pericardioplasties were performed in 20 patients between 6 December 1961 and 10 July 1963. A long-term follow-up study was done in nine patients. In six of these, mitral valvectomy with Starr-Edwards ball valve replacement was required after intervals varying between two years and three months and seven years and three months. In only one of the six cases did the pericardium macroscopically appear normal. In four it was obviously thickened and in two of the four there was also evidence of calcification in the pericardium only. In one of these, calcification was gross, causing complete immobility of the whole $2 \times 0.6$ in $(5 \times 1.7 \mathrm{~cm})$ pericardial inlay. In only one of the six cases had the pericardium become larger and thinner and this also was in the only patient with a dilated mitral ring. Only three patients remain with the pericardium as inserted into the posterior mitral cusp between eight years and eight years and eleven months previously, but in all three there is clinical evidence of progressive pathology in the mitral valve. The progressive mitral valve involvement in this series could well have been caused by progression of the pre-existing pathology in the cusps and chordae tendineae but the involvement of the pericardial inlay was much more extensive than that of the rest of the cusp.
\end{abstract}

Between 6 December 1961 and 10 July 1963, a period when many aspects of prosthetic valve replacement were either unknown or less known than they are today, I attempted the functional reconstruction of the mitral valve with autogenous pericardium in 20 patients with mitral incompetence (van der Spuy, Meintjies, and Human, 1964). It is the aim of this paper to give the findings in a follow-up study of the long-term survivors. Although the series is small, this study has nonetheless been of considerable interest.

Of the 20 patients, nine were in persistent and six in intermittent congestive heart failure, one presented as acute left heart failure (traumatic rupture of anterior cusp during closed mitral valvotomy one week earlier) and four complained chiefly of dyspnoea or fatigue (Table I). Eleven patients had atrial fibrillation and nine were in sinus rhythm. Eleven were females and nine males. Their ages ranged from 12 to 57 years.

T A B L E I

SYMPTOMATOLOGY

\begin{tabular}{|c|c|c|c|c|c|}
\hline \multicolumn{5}{|c|}{ Symptom } & \multirow{4}{*}{$\begin{array}{c}\text { No. } \\
9 \\
6 \\
1 \\
4\end{array}$} \\
\hline \multicolumn{4}{|c|}{$\begin{array}{l}\text { Persistent chronic congestive cardiac failure .. } \\
\text { Intermittent chronic congestive cardiac failure }\end{array}$} & $\ddot{*}$ & \\
\hline Acute left heart failure & . & . & .. & . & \\
\hline Dyspnoea or fatigue & $\cdots$ & . & .. & . & \\
\hline
\end{tabular}

In 18 , severe incompetence was present, and 13 had additional stenosis. In no case was there evidence of significant aortic regurgitation. Twelve patients had marked cardiomegaly and in five of these the cardiothoracic ratio ranged between $80 \%$ and $86 \%$ (Table II). In six patients the valve on digital exploration and direct inspection showed no or minimal stenosis. In the remaining 14 , lesions were of varying degrees of combined stenosis and

T A B L E I I

\begin{tabular}{c|c}
\hline Cardiothoracic Ratio & No. \\
\hline $50-59 \%$ & 8 \\
$60-69 \%$ & 4 \\
$70-79 \%$ & 3 \\
$80-86 \%$ & 5 \\
Average $67 \%$ & \\
\hline
\end{tabular}

T A B LE I I I

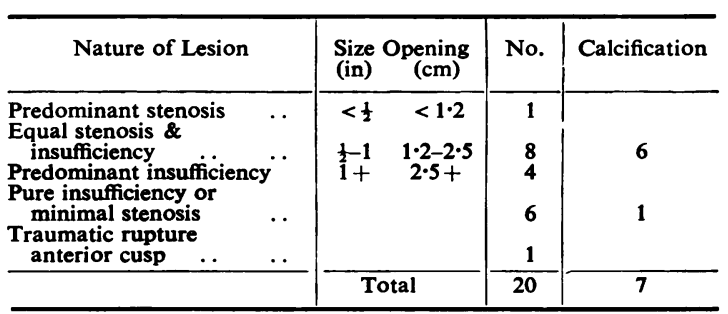


incompetence. In one case the lesion was predominantly stenotic, but severe incompetence was induced during closed mitral valvotomy. This was immediately followed by pericardioplasty. In another patient the anterior cusp was ruptured with a Tubb's mitral valve dilator and pericardioplasty was undertaken seven days later (Table III). Four patients had one or more previous closed mitral valvotomies and one an unsuccessful annuloplasty.

\section{TECHNIQUE}

A standard left posterolateral thoracotomy was used. A sufficiently large area of pericardium was denuded of fat, blood vessels, and, where necessary, mediastinal pleura. The mitral valve was digitally explored through the left atrial appendage and the degree of stenosis and/or incompetence was assessed. The required portion of pericardium was removed immediately before pericardioplasty. This was usually done with the aid of a specially devised (modified Blalock) cusp clamp (Fig. 1) after making an incision, extending from commissure to commissure, either along the

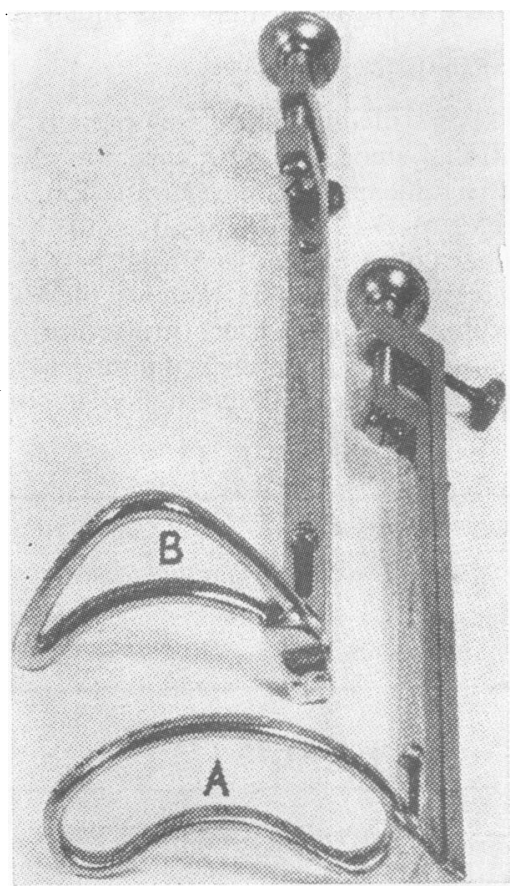

FIG. 1. (A) Posterior cusp clamp; (B) anterior cusp clamp. The clamp was applied to a portion of pericardium from which fat, blood vessels, and mediastinal pleura had been removed, and the proposed cusp, its margins projecting $\pm 3 / 16$ in $(0.48 \mathrm{~cm})$ beyond the outside edge of the clamp, was excised. base of the posterior cusp or just within the peripheraf zone of chordal attachment of the anterior cusp? Closely spaced, interrupted 000 black-braided sutures. were used.

In 17 cases the pericardial inlay was into the posterior cusp, and in three into the anterior cuspo In the first four cases no cusp clamp was used and $a^{\infty}$ portion of pericardium of no measured size or specifies shape was sutured into the basal zone of the posteriorcusp. As it proved very difficult to handle a smallw flimsy portion of pericardium, a posterior cusp clams

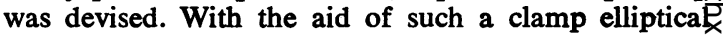
pericardial inlays, measuring $1.5 \times 1$ in $(3.8 \times 0$ $2.5 \mathrm{~cm}$ ), were introduced into the posterior cusp in the next seven cases (Table IV). It soon became apparent that such inlays were at times too small and that com? missural incompetence tended either to persist or to develop after the introduction of such inlays. In each of the next six cases, a larger posterior cusp inlay was constructed with the aid of a sausage-shaped cuspe clamp measuring $2 \times 0.6$ in $(5 \times 1.7 \mathrm{~cm})$. This size and shape proved highly satisfactory. In the following two cases an anterior cusp inlay was done with theo aid of an anterior cusp clamp measuring $1.5 \times 0.6$ in $(3.7 \times 1.7 \mathrm{~cm})$. In the first of these two cases, this resulted in complete correction of the incompetences but in the second, a child of 12 years with gross cardiomegaly, the reconstructed anterior cusp was stilb too small and a moderately severe degree of incompeo tence persisted. She died six weeks postoperatively巴 In the last patient an anterior cusp clamp measuring $2 \times 1$ in $(5 \times 2.5 \mathrm{~cm})$ was used and no incompetence could be felt digitally at the end of the operation, although postoperatively a grade $1 / 6$ systolic murmug was present.

T A B LE IV

\begin{tabular}{|c|c|}
\hline Size of Pericardial Inlay & Case No. \\
\hline 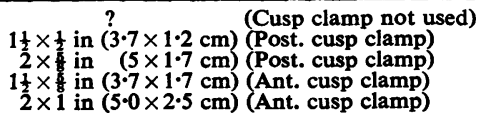 & $\begin{array}{rr}1-4 & (4) \\
5-11 & (7) \\
12-17 & (6) \\
18-19 & (2) \\
20 & (1)\end{array}$ \\
\hline
\end{tabular}

In six of the 20 patients, no incompetence could be felt with an index finger in the left atrium afteo termination of the bypass and with the systemito systolic pressure more or less in the region of the pres operative level. In four minimal, in seven slight, is two moderate, and in one severe incompetence per sisted (Table V). The severe incompetence was du甲 to a faulty technique in case 2 ; as no pericardial clamp was used, the pericardial inlay was difficult to handle and too small, with the result that the mediaf half of the incision into the base of the posterior cusp could not be closed satisfactorily with pericardiumb Otherwise the main cause for persistent incompetenco was too small pericardial inlays. 
T A B L E V

IMMEDIATE POSTOPERATIVE INSUFFICIENCY

\begin{tabular}{llllll|c}
\hline \multicolumn{3}{c}{ Degree } & & & No. \\
\hline Nil & $\ldots$ & $\ldots$ & $\ldots$ & $\ldots$ & $\ldots$ & 6 \\
Minimal & $\ldots$ & $\ldots$ & $\ldots$ & $\ldots$ & $\ldots$ & 4 \\
Slight.. & $\ldots$ & $\ldots$ & $\ldots$ & $\ldots$ & $\ldots$ & 7 \\
Moderate & $\ldots$ & $\ldots$ & $\ldots$ & $\ldots$ & $\ldots$ & 2 \\
Severe.. & $\ldots$ & $\ldots$ & $\ldots$ & $\ldots$ & $\ldots$ & 1 \\
\hline
\end{tabular}

T A B LE V I

CALCIFICATION $(n=7)$

\begin{tabular}{c|l|l}
\hline & Degree & \multicolumn{1}{|c}{$\begin{array}{c}\text { Immediate } \\
\text { Postop. } \\
\text { Insufficiency }\end{array}$} \\
\hline 3 & Sase No. & Vlight \\
7 & Very severe & Nil \\
10 & Very severe & Nil \\
13 & Very severe & Nil \\
16 & Very severe & Minimal \\
18 & Extreme & Minimal \\
\hline Total (7) & Very severe & 1 Slight \\
& All very severe & 2 Minimal \\
\hline
\end{tabular}

T A B LE VII

MORTALITY ANALYSIS

\begin{tabular}{|c|c|c|c|c|}
\hline Cause & & No. & $\begin{array}{l}\text { Postop. } \\
\text { Time }\end{array}$ & $\begin{array}{c}\text { Postop. } \\
\text { Insufficiency }\end{array}$ \\
\hline $\begin{array}{l}\text { Technical-persistent } \\
\text { incompetence } \\
\text { Staphylococcal endocarditis } \\
\text { Dissecting aneurysm } \\
\text { Haemorrhage } \\
\text { Unknown? arrhythmia } \\
\begin{array}{l}\text { Sudden death-arrhythmia } \\
\text { during tracheal toilet }\end{array}\end{array}$ & $\begin{array}{l}\cdots \\
\cdots \\
\cdots \\
\cdots \\
\cdots\end{array}$ & $\begin{array}{l}2 \\
1 \\
1 \\
1 \\
1 \\
1\end{array}$ & $\begin{array}{r}5 \text { weeks } \\
6 \text { weeks } \\
6 \text { weeks } \\
+5 \text { weeks } \\
1 \text { day } \\
1 \text { day } \\
14 \text { days }\end{array}$ & $\begin{array}{l}\text { Severe } \\
\text { Moderate } \\
\text { Nil } \\
\text { Slight } \\
\text { Slight } \\
\text { Nil } \\
\text { Nil }\end{array}$ \\
\hline $\begin{array}{lll}\text { Total } & \ldots & \ldots\end{array}$ & $\ldots$ & 7 & & \\
\hline
\end{tabular}

Seven of the 20 patients had very extensive valve calcification (Table VI). Four of these patients died. In spite of the very severe degree of calcification, four patients had no, two minimal, and one slight postoperative incompetence.
A total of seven patients died (Table VII). In two of these, death was due to an unsatisfactory operative result. Staphylococcal endocarditis caused the death of one patient and a dissecting aneurysm of the aorta that of another five weeks postoperatively. Postoperative haemorrhage was the major cause of death of a fifth patient. The sixth patient died very suddenly and unexpectedly on the first postoperative day, probably as the result of an arrhythmia. The seventh was a man of 57 who suffered from a severe degree of chronic bronchitis for which he had been receiving steroid therapy. His wound ruptured one day after removal of the sutures. Cardiac arrest developed during secondary suture of the wound. He recovered after rhythmic cardiac compression and defibrillation. Three days later, during endotracheal toilet through a tracheostomy tube, he suddenly collapsed and died from ventricular arrhythmia.

Of the remaining 13 patients, four came from outlying rural areas. Of these, one, with a cardiothoracic ratio of $85 \%$, died some months after discharge from hospital from an unknown cause. Two were completely lost to follow-up. The fourth was followed up for two years and one month only.

\section{FOLLOW-UP STUDY}

Only nine patients were therefore available for long-term follow-up study. In six of the nine patients valvectomy with Starr-Edwards ball valve replacement was required from two years and three months to seven years and three months postoperatively with a mean of four years and six months (Table VIII). The indications for ball valve replacement were recurrent progressive incompetence (dilated ring) in one, progressive stenosis in another, and progressive stenosis and incompetence in the remaining four patients. Of these six patients, one had mild (dilated ring for which annuloplasty was not done), two minimal, and three no incompetence immediately after pericardioplasty. At reoperation, in only one of these six patients was the pericardium larger and thinner than at the time of pericardioplasty two

T A B L E V I I I

PERICARDIOPLASTY: STARR-EDWARDS BALL VALVE

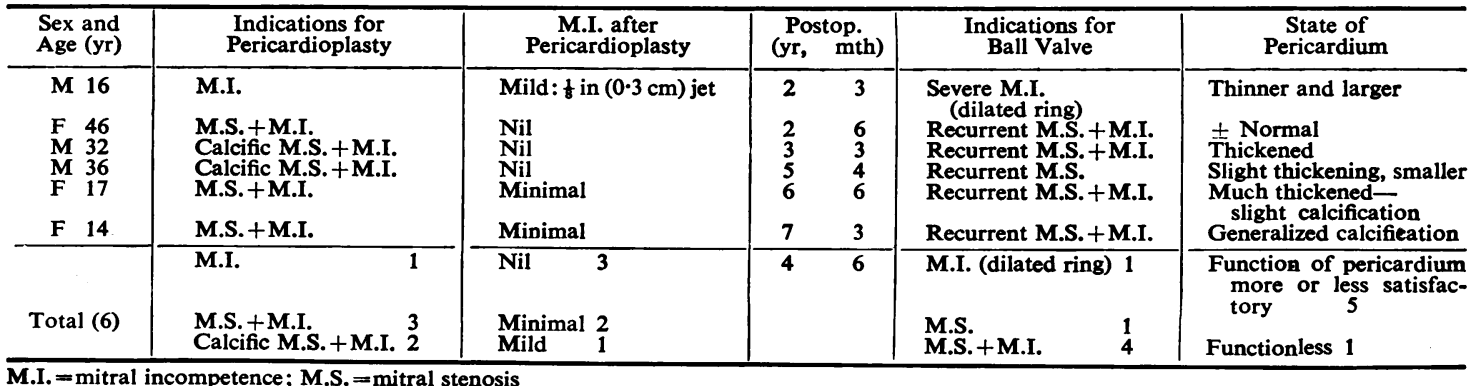




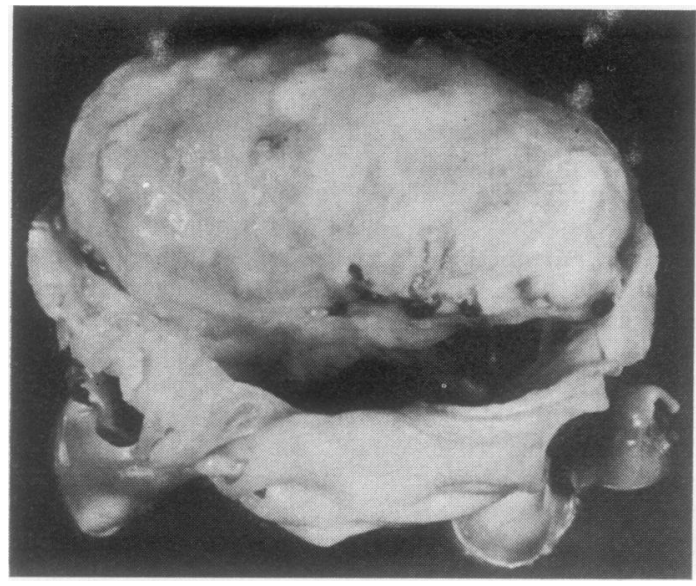

FIG. 2. Atrial view of excised mitral valve. The autogenous pericardial inlay, measuring $2 \times 0.6$ in $(5 \times 1.7 \mathrm{~cm})$, into the posterior cusp of the mitral valve seven years and three months previously had become grossly calcified and completely immobile in the systolic position. The calcification was limited to the inlay. years and three months previously. This also was the only patient who had a dilated ring. This would seem to indicate that ring dilatation can $\stackrel{\oplus}{+}$ in itself be a cause of enlarged mitral cusps. In the remaining five cases, in only one did the peri- $\overline{\bar{c}}$ cardium not obviously appear altered in size or thickness on macroscopic examination. In the second of these, the inlay was much thickened only; in another it was thickened and smaller, in $\overrightarrow{0}$ the fourth much thickened with slight calcification:(after six years and six months), and in the fifth $\vec{\omega}$ patient there was generalized gross calcification with complete immobility of the pericardial inlay $\vec{x}$ only (after seven years and three months) (Fig. 2). iv In the latter case the pericardium became calcified iv in the systolic position, which indicated that as $\mathrm{N}$ the valve stiffened its position could eventually be influenced by systolic pressure only. The 음 calcified inlay also limited the anteroposterior $\rightarrow$ diameter of the valve opening, thus significantly contributing to the adverse effects of the com- $\overline{\widetilde{O}}$ missural restenosis which had also taken place. $\stackrel{\bigcirc}{\supset}$ The rest of the valve was not calcified.

T A B L E I X

PERICARDIOPLASTY ONLY

\begin{tabular}{|c|c|c|c|c|c|}
\hline $\begin{array}{c}\text { Sex } \\
\text { and } \\
\text { Age (yr) }\end{array}$ & Indication & $\begin{array}{l}\text { M.I. after } \\
\text { Pericardioplasty }\end{array}$ & $\begin{array}{l}\text { Postop. } \\
\text { (yr, mth) }\end{array}$ & Present Status & $\begin{array}{l}\text { Progress } \\
\text { of Pathology } \\
\text { Clinically }\end{array}$ \\
\hline $\begin{array}{l}\text { F } 22 \\
\text { F } 28 \\
\text { F } 28\end{array}$ & $\begin{array}{l}\text { M.I. } \\
\text { M.I. + M.S. } \\
\text { M.I. }\end{array}$ & $\begin{array}{l}\text { Nil } \\
\text { Nil } \\
\text { Minimal }\end{array}$ & $\begin{array}{r}0 \\
2 \\
11\end{array}$ & $\begin{array}{l}\text { M.S. minimal; M.I. nil; } \\
\text { grade } 1 / 6 \text { mid-diastolic rumble } \\
\text { M.S. moderate; M.I. minimal } \\
\text { M.I. significant }\end{array}$ & $\begin{array}{l}\text { Yes } \\
\text { Yes } \\
\text { Yes }\end{array}$ \\
\hline Total (3) & $\begin{array}{l}\text { M.I. } \\
\text { M.I. + M.S. } 1\end{array}$ & $\begin{array}{ll}\text { Nil } & 2 \\
\text { Minimal } & 1\end{array}$ & 8 & $\begin{array}{l}\text { M.I. minimal; M.S. moderate } 1 \\
\text { M.I. significant } \\
\text { M.I. nil; minimal M.S. }\end{array}$ & Yes 3 \\
\hline
\end{tabular}
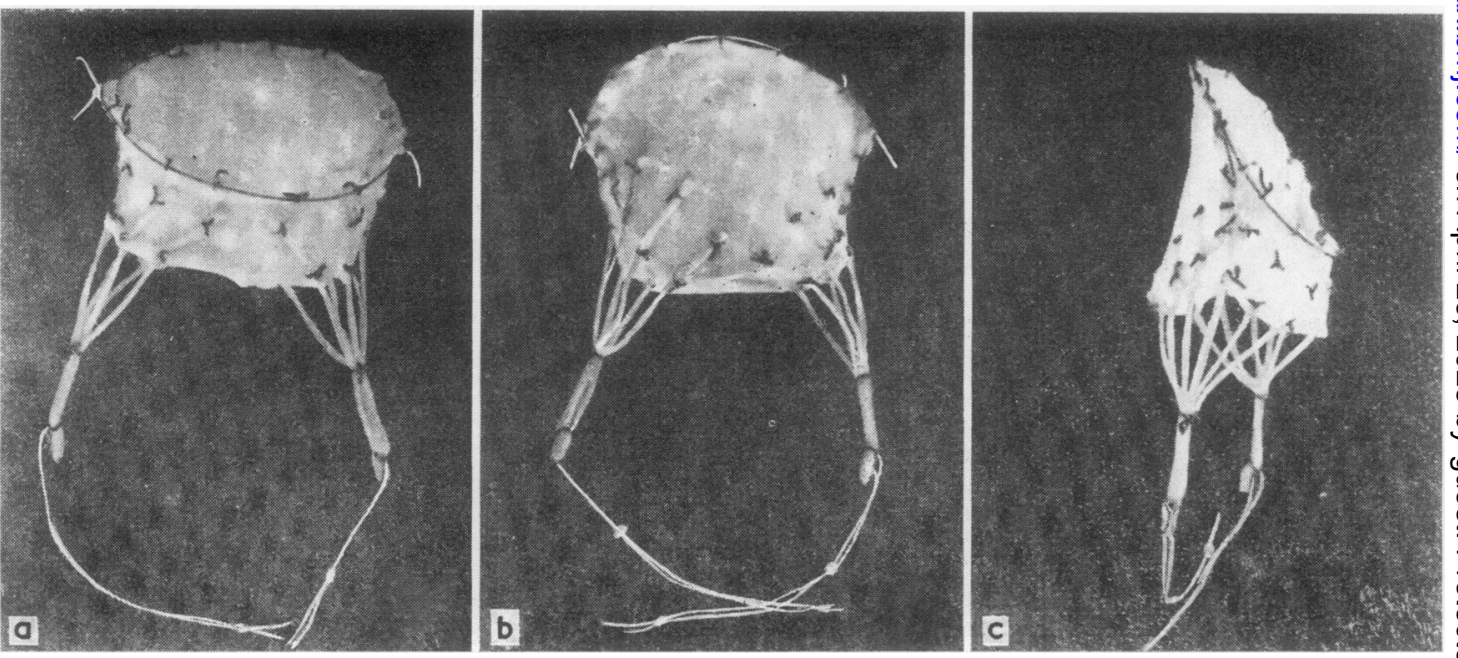

FIG. 3. A fully anatomical whole mitral valve with the cusps from autogenous pericardium and chordae tendineae from autogenous fascia lata: (a) posterior view; (b) anterior view; (c) lateral view. 


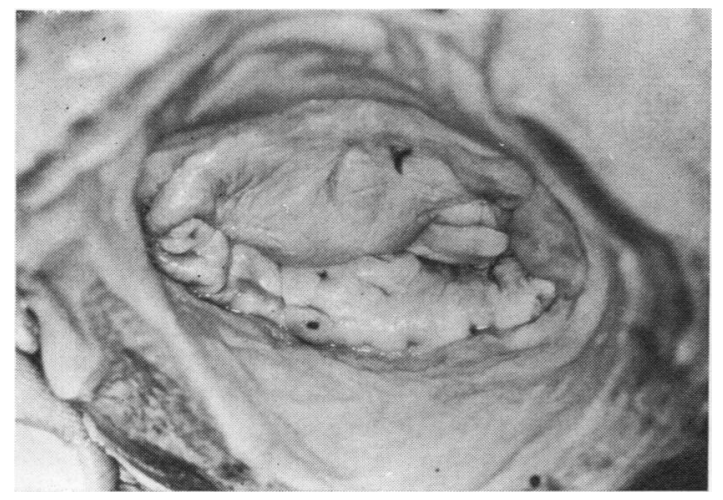

FIG. 4. Left atrial view of fully anatomical autogenous whole mitral valve after six months. The pericardial cusps were thickened and leathery.

In three patients only has mitral valvectomy not become necessary subsequent to pericardioplasty. In all of these, however, there is clinical evidence of progressive pathology in the mitral valve. In one, who initially had pure mitral incompetence, with no incompetence after pericardioplasty, evidence of mild mitral stenosis was first diagnosed on auscultation seven years and six months after operation. The second case initially had pure mitral incompetence, which, although slight after pericardioplasty, has since become steadily progressive. In the third, although no evidence of stenosis was present after seven years, it could clearly be heard on auscultation after eight years and two months, and mild calcification could be seen on screening with an image intensifier. No calcification could, however, be seen in the other two cases (Table IX).

In one patient, not included in this series, after total replacement of the valve with a fully anatomical valve with cusps from the pericardium and chordae tendineae from threads of autogenous fascia lata (van der Spuy, 1964 (Fig. 3),

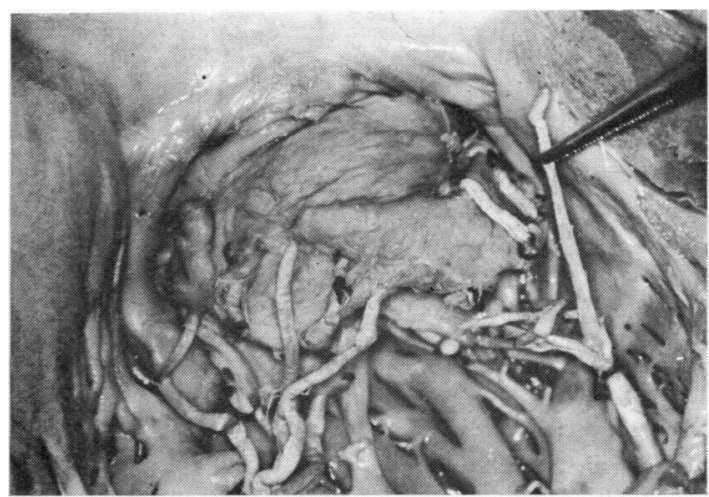

FIG. 5. Left ventricular view of fully anatomical autogenous whole mitral valve after six months. The chordae tendineae closely resembled the original fascia lata macroscopically.

the cusps were thickened and somewhat leathery after six months (Fig. 4). On microscopy the pericardium of both valve cusps consisted of collagenous tissue in which viable fibroblast nuclei were present. The chordae tendineae, however, microscopically consisted of acellular collagen with slight fibroblastic ingrowth in the region of the pericardium. The cause of death was gross incompetence due to lack of adhesion of some of the chordae tendineae to the cusps. Some chordae tendineae either pulled out from the anchoring sutures or were divided by these encircling sutures. The remaining chordae had to a greater or lesser degree become fused with the pericardial cusps (Fig. 5).

\section{REFERENCES}

van der Spuy, J. C. (1964). Completely anatomical autogenous whole mitral valve. Thorax, 19, 526.

- Meintjies, F. A., and Human, G. (1964). The surgical approach to the mitral valve and the technique of correcting insufficiency of the anterior and of the posterior cusp with pericardium. S. Afr. med.J., 38, 554. 